Prepared in cooperation with the U.S. Department of the Army Environmental and Natural Resources Management Office of the U. S. Army Signal Center and Fort Gordon

\title{
Quantity and Quality of Stormwater Collected from Selected Stormwater Outfalls at Industrial Sites, Fort Gordon, Georgia, 2011
}

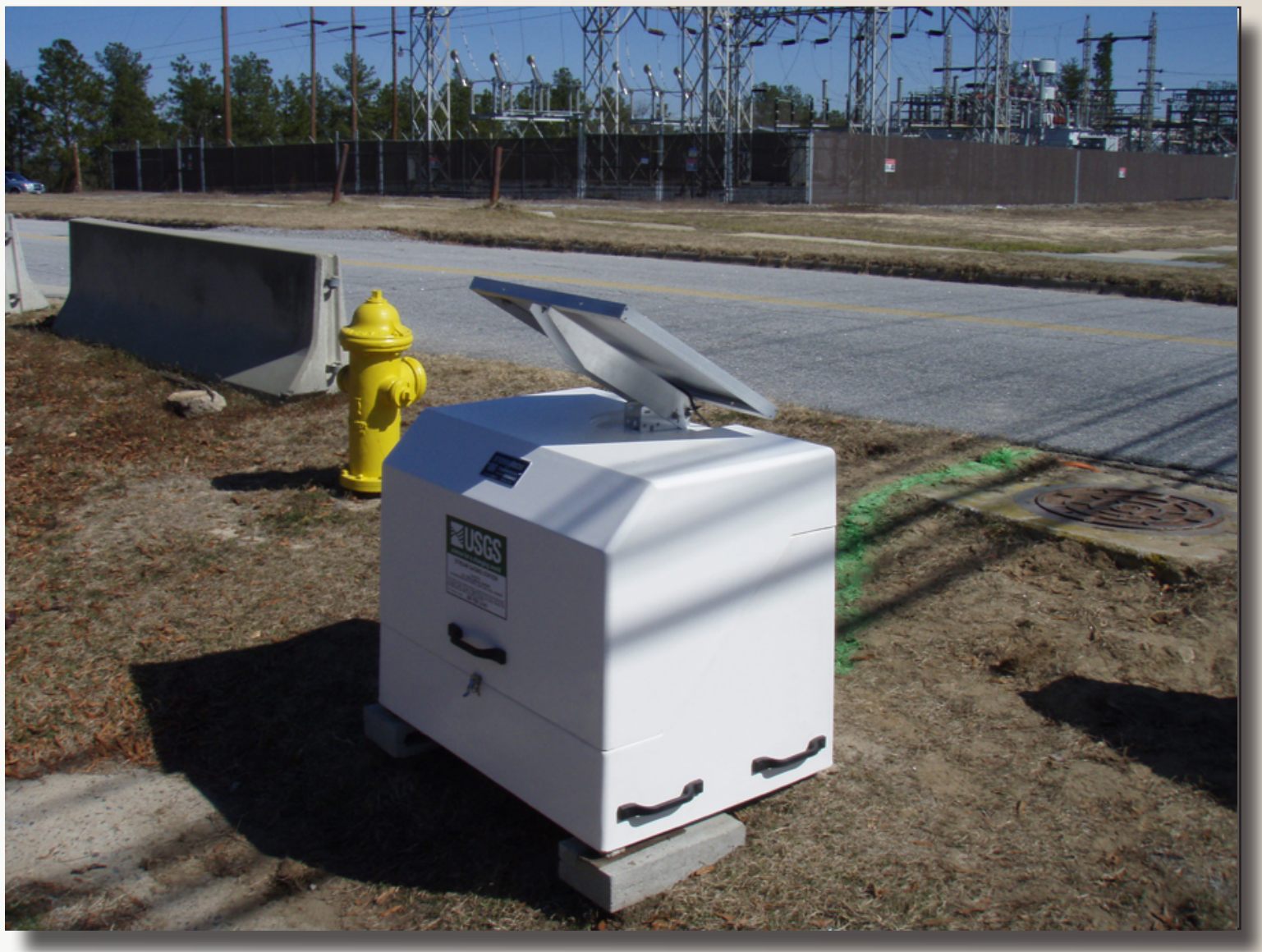

Open-File Report 2012-1035 
Cover. Automatic sampler housing located at Site 4 H\&C 25910 outfall 1, Fort Gordon, Georgia.

Photograph by Kevin Conlon, U.S. Geological Survey. 


\section{Quantity and Quality of Stormwater Collected from Selected Stormwater Outfalls at Industrial Sites, Fort Gordon, Georgia, 2011}

By Doug D. Nagle and Wladmir B. Guimaraes

Prepared in cooperation with the U.S. Department of the Army Environmental and Natural Resources Management Office of the U.S. Army Signal Center and Fort Gordon

Open-File Report 2012-1035 


\section{U.S. Department of the Interior \\ KEN SALAZAR, Secretary \\ U.S. Geological Survey \\ Marcia K. McNutt, Director}

\section{U.S. Geological Survey, Reston, Virginia: 2012}

For more information on the USGS — the Federal source for science about the Earth, its natural and living resources, natural hazards, and the environment, visit http://www.usgs.gov or call 1-888-ASK-USGS.

For an overview of USGS information products, including maps, imagery, and publications, visit http://www.usgs.gov/pubprod

To order this and other USGS information products, visit http://store.usgs.gov

Any use of trade, product, or firm names is for descriptive purposes only and does not imply endorsement by the U.S. Government.

Although this report is in the public domain, permission must be secured from the individual copyright owners to reproduce any copyrighted materials contained within this report.

Suggested citation:

Nagle, D.D., and Guimaraes, W.B., Quantity and quality of stormwater collected from selected stormwater outfalls at industrial sites, Fort Gordon, Georgia, 2011: U.S. Geological Survey Open-File Report 2012-1035, 18 p. 


\section{Contents}

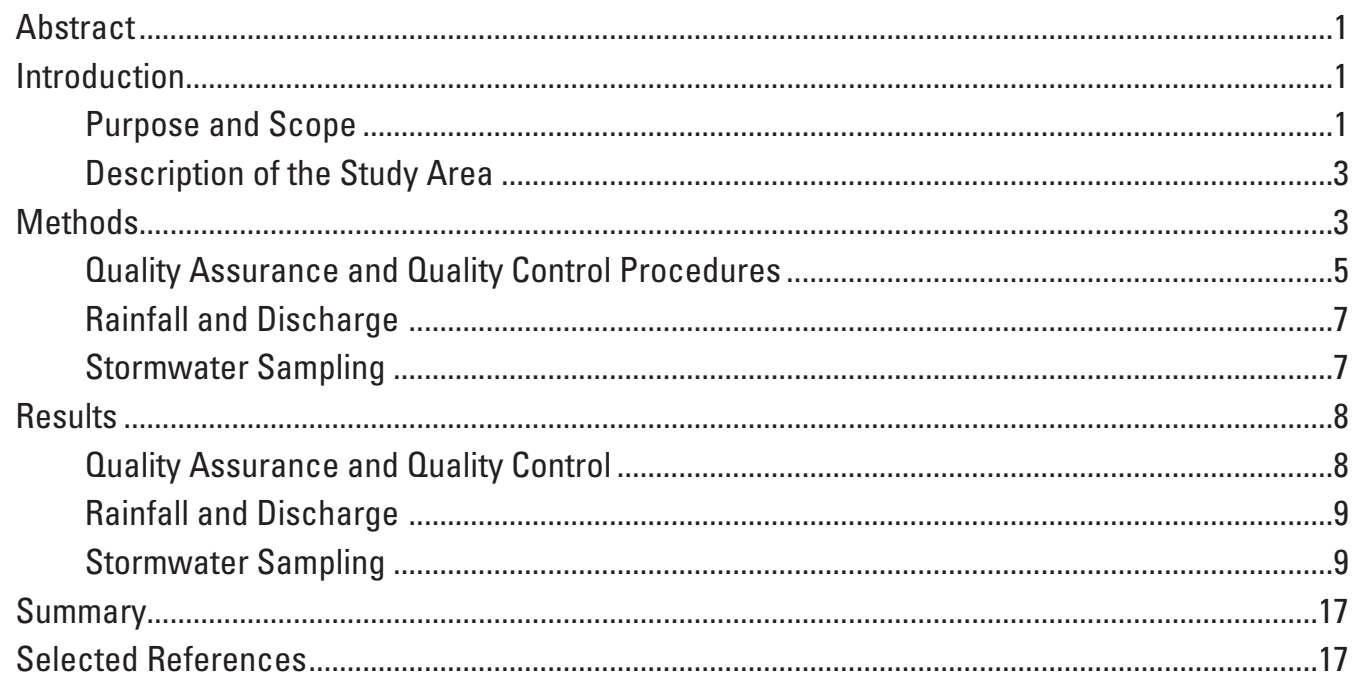

\section{Figures}

1. Maps showing location of stormwater industrial sites scheduled to be sampled

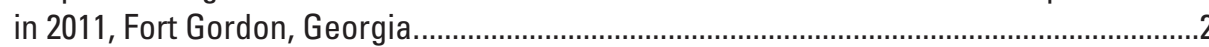

2. Map and photographs showing location of stormwater sampling sites scheduled to be sampled in 2011, Fort Gordon, Georgia..

3. Photographs showing retention and detention ponds at the landfill sites, Fort Gordon, Georgia.

4. Photograph showing automatic sampler and rain gage installed at selected industrial sites, Fort Gordon, Georgia.

\section{Tables}

1. Station identification name and number, and classification type for stations where stormwater runoff was scheduled to be sampled in 2011, Fort Gordon, Georgia

2. Type of constituents sampled and method of analysis for stormwater samples at Fort Gordon, Georgia, 2011

3. Streamflow and rainfall amounts, date that sample was collected, number of days from last measurable rain event and duration of rain event, Fort Gordon, Georgia, 2011

4. Results of the field blank submitted for the stormwater runoff sampling, Fort Gordon, Georgia, 2011

5. Field parameters detected in stormwater samples collected from selected stormwater industrial sites, Fort Gordon, Georgia, 2011

6. Suspended material, nutrients and organic compounds, and major and trace inorganic compounds detected in a single grab stormwater sample taken within the first 30 minutes of runoff from heating and cooling station SWR11-3, Fort Gordon, Georgia, September 5, 2011 


\section{Tables-Continued}

7. Suspended material, nutrients and organic compounds, and major and trace inorganic compounds detected in a single grab stormwater sample taken within the first 30 minutes of runoff from heating and cooling station SWR11-4, Fort Gordon, Georgia, October 18, 2011

8. Suspended material, nutrients and organic compounds, and major and trace inorganic compounds detected in a single grab stormwater sample taken within the first 30 minutes of runoff from heating and cooling station SWR11-5, Fort Gordon, Georgia, October 18, 2011.

9. Volatile and semivolatile organic compounds detected in a single stormwater grab sample taken within the first 30 minutes of runoff from heating and cooling station SWR11-3, Fort Gordon, Georgia, September 5, 2011.-Continued

10. Volatile and semivolatile organic compounds detected in a single stormwater grab sample taken within the first 30 minutes of runoff from heating and cooling station SWR11-4, Fort Gordon, Georgia, October 18, 2011

11. Volatile and semivolatile organic compounds detected in a single stormwater grab sample taken within the first 30 minutes of runoff from heating and cooling station SWR11-5, Fort Gordon, Georgia, October 18, 2011 


\section{Conversion Factors}

Inch/Pound to SI

\begin{tabular}{lcc}
\hline & Multiply & By obtain \\
\hline inch (in.) & Length & centimeter $(\mathrm{cm})$ \\
inch (in.) & 2.54 & millimeter $(\mathrm{mm})$ \\
foot (ft) & 25.4 & meter $(\mathrm{m})$ \\
mile (mi) & 0.3048 & kilometer $(\mathrm{km})$ \\
\hline & 1.609 & \\
\hline cubic foot per second $\left(\mathrm{ft}^{3} / \mathrm{s}\right)$ & Flow rate & cubic meter per second $\left(\mathrm{m}^{3} / \mathrm{s}\right)$ \\
\hline
\end{tabular}

Horizontal coordinate information is referenced to the North American Datum of 1983 (NAD 83).

\section{Additional Abbreviations and Acronyms}

$\begin{array}{ll}\text { GaDNR } & \text { Georgia Department of Natural Resources } \\ \text { H\&C } & \text { heating and cooling } \\ \text { LRL } & \text { laboratory reporting limit } \\ \mathrm{mg} / \mathrm{L} & \text { milligram per liter } \\ \mu \mathrm{g} / \mathrm{L} & \text { microgram per liter } \\ \text { MDL } & \text { method detection level } \\ \text { NPDES } & \text { National Pollutant Discharge Elimination System } \\ \text { NWIS } & \text { National Water Information System } \\ \text { NWOL } & \text { National Water-Quality Laboratory } \\ \text { OA } & \text { quality assurance } \\ \text { OC } & \text { quality control } \\ \text { SDI-12 } & \text { serial data interface at 12 baud } \\ \text { USEPA } & \text { U.S. Environmental Protection Agency } \\ \text { USGS } & \text { U.S. Geological Survey } \\ \text { SWP3 } & \text { Stormwater Pollution Prevention Plan }\end{array}$




\title{
Quantity and Quality of Stormwater Collected from Selected Stormwater Outfalls at Industrial Sites, Fort Gordon, Georgia, 2011
}

\author{
By Doug D. Nagle and Wladmir B. Guimaraes
}

\section{Abstract}

An assessment of the quantity and quality of stormwater runoff associated with industrial activities at Fort Gordon was conducted from January through December 2011. The assessment was provided to satisfy the requirements from a general permit that authorizes the discharge of stormwater under the National Pollutant Discharge Elimination System from a site associated with industrial activities. The stormwater quantity refers to the runoff discharge at the point and time of the runoff sampling. The study was conducted by the U.S. Geological Survey, in cooperation with the U.S. Department of the Army Environmental and Natural Resources Management Office of the U.S. Army Signal Center and Fort Gordon.

The initial scope of this study was to sample stormwater runoff from five stations at four industrial sites (two landfills and two heating and cooling sites). As a consequence of inadequate hydrologic conditions during 2011, no samples were collected at the two landfills; however, three samples were collected from the heating and cooling sites.

The assessment included the collection of physical properties, such as water temperature, specific conductance, dissolved oxygen, and $\mathrm{pH}$; the detection of suspended materials (total suspended solids, total fixed solids, total volatile solids), nutrients and organic compounds, and major and trace inorganic compounds (metals); and the detection of volatile and semivolatile organic compounds. Nutrients and organic compounds, major and trace inorganic compounds, and volatile and semivolatile organic compounds were detected above the laboratory reporting levels in all samples collected from the three stations. The detection of volatile and semivolatile organic compounds included anthracene, benzo[a]anthracene, benzo[ $[a]$ pyrene, benzo[ghi]perylene, cis, 1, 2-dichloroethene, dimethyl phthalate, fluoranthene, naphthalene, pyrene, acenaphthylene (station SWR11-3), and di-n-butyl phthalate (station SWR11-4).

\section{Introduction}

Fort Gordon is a U.S. Department of the Army facility located in east-central Georgia, approximately 10 miles (mi) outside of Augusta, Georgia (fig. 1). Five outfalls on four industrial sites located within the Fort Gordon area were scheduled to be sampled to determine the water quantity and quality of the runoff from January through December 2011 (fig. 1). The quantity of the runoff refers to the discharge measured at the time and location of the sample. The U.S. Department of the Army uses water-quality information from stormwater samples to support development of a Stormwater Pollution Prevention Plan (SWP3) as required by the State of Georgia Department of Natural Resources (GaDNR) Environmental Protection Division under a general permit to discharge stormwater associated with industrial activities (Georgia Department of Natural Resources, 2006). An effective SWP3 ensures that natural resource conservation measures and Army activities are consistent with National Pollutant Discharge Elimination System (NPDES) Federal and State requirements to manage such installations. Under the general permit, numeric effluent limitations have been established for industrial facilities through the NPDES (Georgia Department of Natural Resources, 2006). Numeric limitations are assigned for landfills, but no numeric limitations are listed for heating and cooling sites.

\section{Purpose and Scope}

The purpose of this report is to describe the quantity and quality of stormwater collected from January through December 2011 by the U.S. Geological Survey (USGS) at selected stormwater outfall locations associated with industrial activities at Fort Gordon, Georgia. The U.S. Army at Fort Gordon was provided water-quality data from a single storm event at the selected outfalls. The stormwater data are needed to support the SWP3 and be in compliance with the general permit that allows discharges from sites associated with industrial activities (Georgia Department of Natural Resources, 2006). The stormwater sampling targeted stormwater runoff 

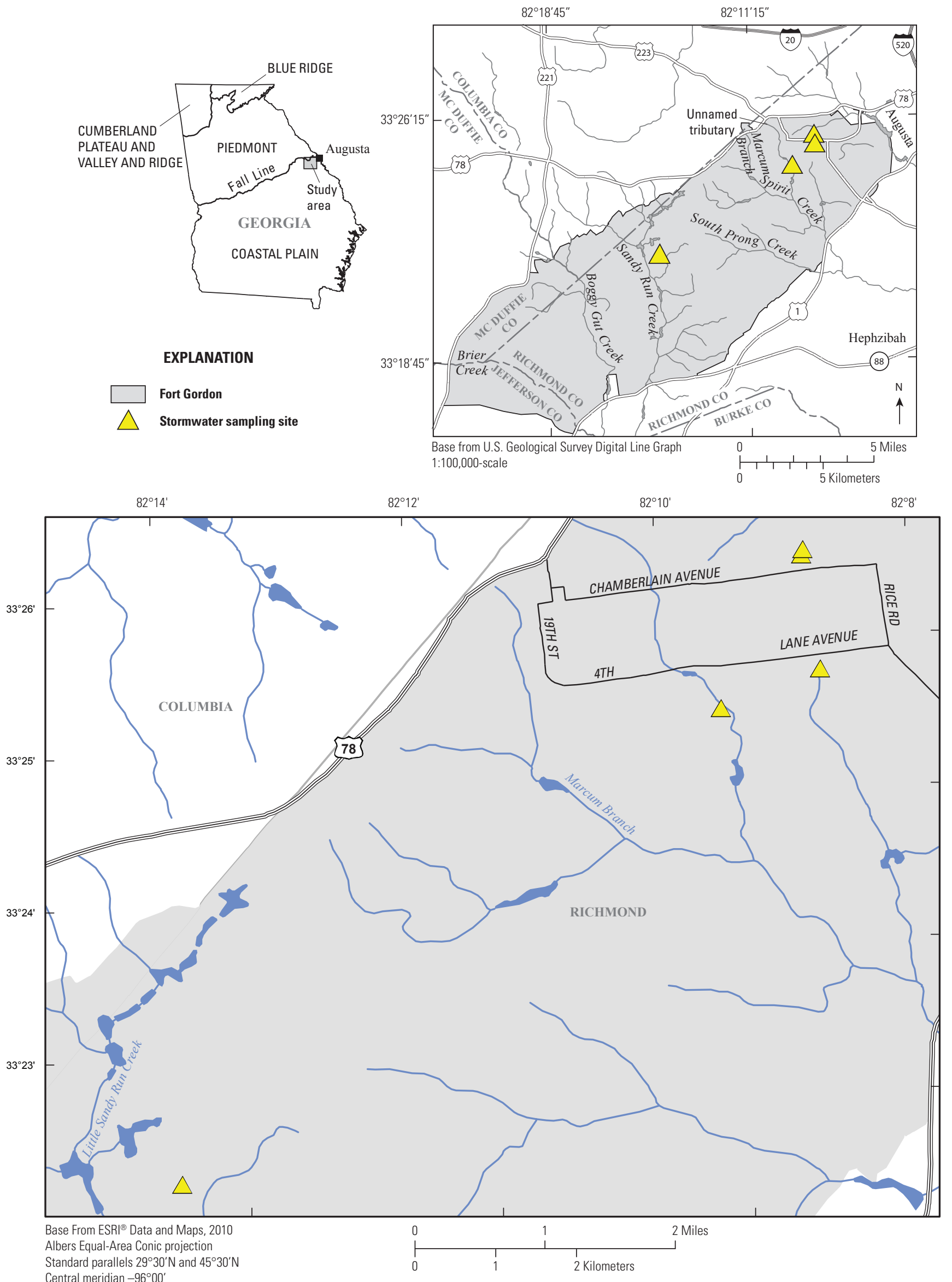

Figure 1. Location of stormwater industrial sites scheduled to be sampled in 2011, Fort Gordon, Georgia. 
at five outfall locations from four sites (fig. 2). Two outfalls were sampled from a single industrial site. Although five outfall locations were targeted to be sampled, storm conditions were conducive for sampling at only three of the five outfall locations.

\section{Description of the Study Area}

Fort Gordon is a U.S. Army facility located in eastcentral Georgia, approximately $10 \mathrm{mi}$ southwest of Augusta, Georgia (fig. 1). Fort Gordon lies in the northern part of the Coastal Plain Physiographic Province and south of the Fall Line. Surficial soil and sediments are characterized by the unconsolidated sands, indurated sands and semiconsolidated sandstones, and layers of clay that include kaolinite (Gregory and others, 2001).

For this study, two of the five outfall locations scheduled for sampling were classified as landfill sites (site SWR11-1, Gibson Road landfill; and site SWR11-2, 17 $7^{\text {th }}$ Street landfill) (table 1, fig. 2). The remaining three outfall locations were classified as heating and cooling (H\&C) plants (site SWR11-3, H\&C plant \# 310; and sites SWR11-4 and SWR11-5, H\&C plant \# 25910) (table 1, fig. 2). Impervious surface covers much of drainage area at the $\mathrm{H} \& \mathrm{C}$ plants. Because of this site characteristic, only minor infiltration occurs during storm events and sufficient discharge at the associated stormwater outfall is available for sampling during most storm events. Conversely, landfill areas have negligible impervious cover. This allows stormwater to infiltrate and requires much greater rainfall amounts before sufficient discharge at the associated stormwater outfall is available for sampling. Furthermore, runoff at the landfill sites must first fill a retention (SWR11-1) or detention (SWR11-2) pond before the discharge can be sampled and measured at the outfall location (fig. 3). Therefore, the landfills sites were not sampled because rainfall amounts at the landfill sites were inadequate to meet criteria needed for sample collection during the calendar year 2011.

\section{Methods}

All samples were collected and processed using standard USGS and GaDNR field procedures (U.S. Geological Survey, variously dated; Georgia Department of Natural Resources, 2006). The stormwater samples were collected as grab samples during the first 30 minutes of storm runoff at three $\mathrm{H} \& \mathrm{C}$ outfalls. Criteria for sampling required that each storm event produce at least 0.1 inch (in.) of rain 72 hours after the last measurable (more than 0.1 in.) rain event (Georgia Department of Natural Resources, 2006). During each runoff event, automatic samplers were prepared to collect water samples at the outfall in pre-cleaned, acid-rinsed plastic containers. The samplers were automated to collect samples and measure discharge based on the preprogrammed settings. If the samplers did not automatically sample, they were manually operated to collect the sample and the discharge. Finally, if the flow depth was not sufficient to allow the automatic sampler to collect the samples, the samples were collected manually and the discharge was computed indirectly. The individual samples were processed in the field prior to shipment to the laboratory. Sample processing included preparation (for example, compositing and filtering) and preservation (for example, acidification) of the final composite sample (U.S. Geological Survey, variously dated). Procedures that were followed were specific to the constituent that was analyzed. Pre-cleaned, acid-rinsed 8-liter (L) plastic churns were used as the compositing devices. For analysis of dissolved constituents, samples were filtered using 0.45 -micron glass-fiber capsule filters that were conditioned with $2 \mathrm{~L}$ of deionized water. A summary of analytical methods for stormwater samples is listed in table 2 .

Physical properties (dissolved oxygen, specific conductance, water temperature, and $\mathrm{pH}$ ) were measured in the field using a calibrated field meter. Water samples were analyzed for constituents appropriate for each site (table 2). Samples were analyzed for nutrients, trace metals, hardness, total suspended solids, total organic carbon, chemical oxygen demand, volatile organic compounds, and semivolatile organic compounds by the USGS National Water-Quality Laboratory (NWQL) in Lakewood, Colorado (information on laboratory available at http://nwql.usgs.gov/Public/Profile/index. $\mathrm{htm})$. Samples were analyzed for oil and grease by TestAmerica located in Denver, Colorado (information on laboratory available at www.testamericainc.com/home_alt.aspx). Total organic nitrogen and ammonia and total phosphorus concentrations were determined by analyses described by Patton and Kryskalla (2003). Dissolved and total trace metal concentrations were determined by inductively coupled plasma-optical emission spectrometry and inductively coupled plasma mass spectrometry (Fishman and Friedman,1989; Fishman, ed., 1993; Hoffman and others, 1996; Garbarino and Struzeski, 1998; Garbarino and Damrau, 2001; Garbarino and others, 2006). Total suspended solid concentrations were measured by analytical methods used to quantify concentrations of suspended organic and inorganic particles in surface waters (Fishman and Friedman, 1989). Total organic carbon was measured on whole water samples according to standard method 5310B (Standard methods for the Examination of Water and Wastewater High-Temperature Combustion Method, 1998). Chemical oxygen demand was measured on whole water samples according by the colorimetric dichromatic oxidation HACH method (Fishman and Friedman, 1989). Volatile organic compounds were determined by using purge-and-trap capillary-column gas chromatography and mass spectrometry methods described by Connor and others (1998). Semivolatile organic compounds were measured by continuous liquid-liquid extraction and capillary-column gas chromatography and mass spectrometry analytical methods used to determine inorganic and organic constituents in water and fluvial sediemnts (Fishman, 1993). Oil and grease concentrations were determined according to USEPA method 1664A (U.S. Environmental Protection Agency, 1999a). 


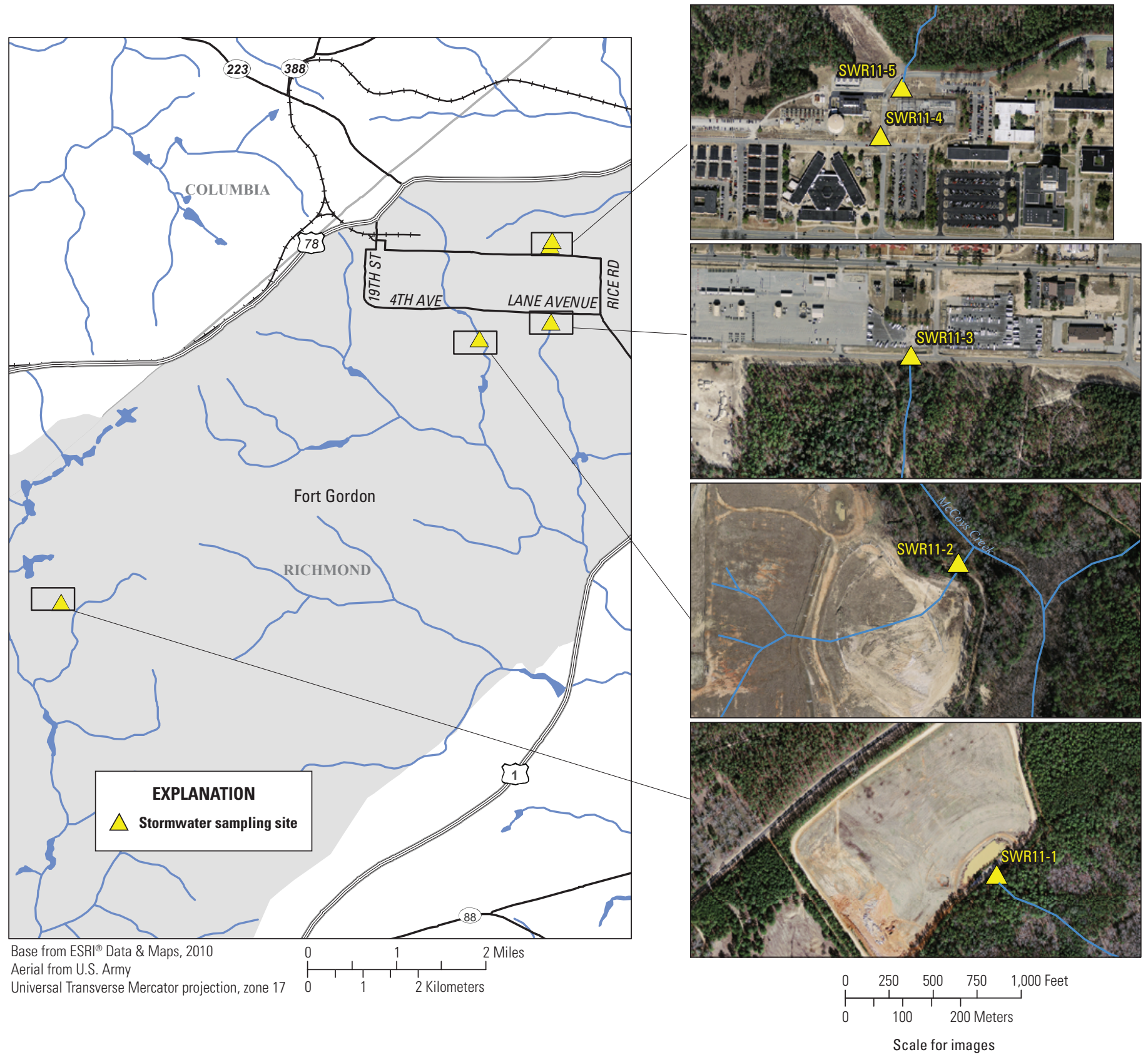

Figure 2. Location of stormwater sampling sites scheduled to be sampled in 2011, Fort Gordon, Georgia. 
Table 1. Station identification name and number, and classification type for stations where stormwater runoff was scheduled to be sampled in 2011, Fort Gordon, Georgia.

[USGS, U.S. Geological Survey]

\begin{tabular}{|c|c|c|c|c|c|}
\hline $\begin{array}{l}\text { USGS station } \\
\text { identification } \\
\text { number }\end{array}$ & $\begin{array}{c}\text { USGS station } \\
\text { name } \\
\text { (figure 1) }\end{array}$ & Classification type & Description & Latitude & Longitude \\
\hline 332205082143100 & SWR11-1 & Landfill & Gibson Road Landfill & $33^{\circ} 22^{\prime} 05^{\prime \prime}$ & $82^{\circ} 14^{\prime} 31^{\prime \prime}$ \\
\hline 332442082094100 & SWR11-2 & Landfill & 17th Street Landfill & $33^{\circ} 24^{\prime} 42^{\prime \prime}$ & $82^{\circ} 09^{\prime} 41^{\prime \prime}$ \\
\hline 332452082085100 & SWR11-3 & $\begin{array}{l}\text { Heating and cooling } \\
\text { plant }\end{array}$ & $\begin{array}{l}\text { Heating and cooling } \\
\text { plant } \# 310\end{array}$ & $33^{\circ} 24^{\prime} 52^{\prime \prime}$ & $82^{\circ} 08^{\prime} 51^{\prime \prime}$ \\
\hline 332538082085200 & SWR11-4 & $\begin{array}{l}\text { Heating and cooling } \\
\text { plant }\end{array}$ & $\begin{array}{l}\text { Heating and cooling } \\
\text { plant } \# 25910\end{array}$ & $33^{\circ} 25^{\prime} 38^{\prime \prime}$ & $82^{\circ} 08^{\prime} 52^{\prime \prime}$ \\
\hline 332540082085100 & SWR11-5 & $\begin{array}{l}\text { Heating and cooling } \\
\text { plant }\end{array}$ & $\begin{array}{l}\text { Heating and cooling } \\
\text { plant } \# 25910\end{array}$ & $33^{\circ} 25^{\prime} 40^{\prime \prime}$ & $82^{\circ} 08^{\prime} 51^{\prime \prime}$ \\
\hline
\end{tabular}

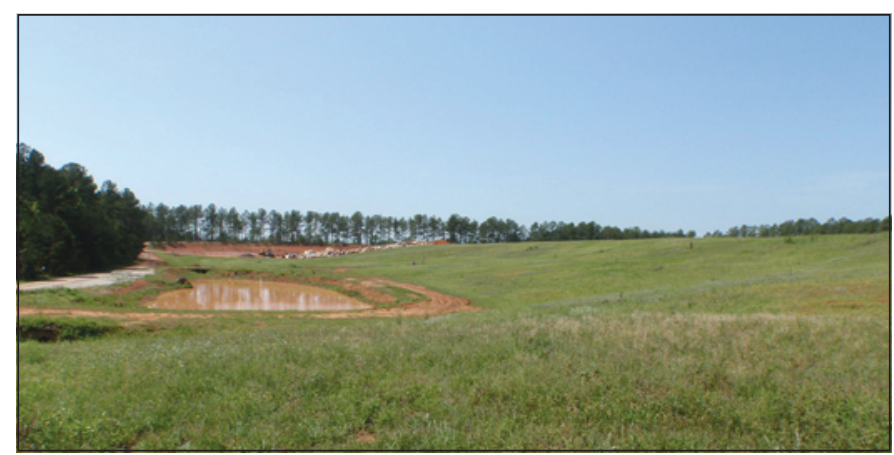

Retention pond (SWR11-1)

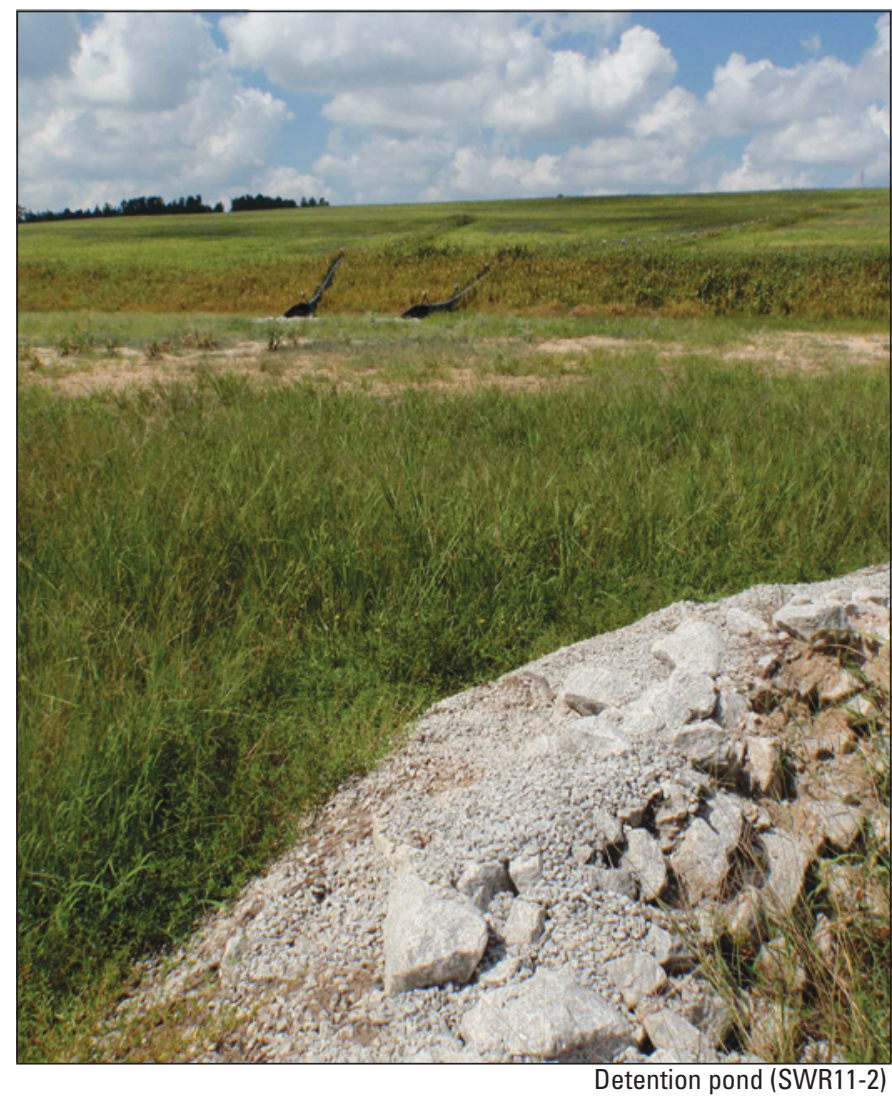

Figure 3. Retention and detention ponds at the landfill sites, Fort Gordon, Georgia.
Handling censored data appropriately is necessary when laboratories report quantitative, estimated, and censored results: (1) Results above a laboratory reporting level (LRL) are reported as a quantitative value. (2) Results below the LRL and above the method detection level (MDL) are estimated (because the values are considered semiquantitative) and are reported with the remark code (E). (3) Results below the nondetection level are reported as censored data, and were reported as less than the LRL (Childress and others, 1999). For example, if the LRL for total recoverable cadmium concentration is 0.4 microgram per liter $(\mu \mathrm{g} / \mathrm{L})$, but was detected above the MDL of $0.2 \mu \mathrm{g} / \mathrm{L}$, then an estimated value of $0.3 \mu \mathrm{g} / \mathrm{L}$ may be reported.

\section{Quality Assurance and Quality Control Procedures}

Quality assurance (QA) and quality control (QC) procedures maintain the integrity, accuracy, and legal defensibility of results from data collection and assessment (U.S. Environmental Protection Agency, 2009). For this study, the QA procedures included the sampling techniques, stewardship of the samples, and laboratory analyses. The QA for the sampling protocols were maintained by adherence to established procedures of the USGS and GaDNR Environmental Protection Division (U.S. Geological Survey, variously dated; Georgia Department of Natural Resources, 2006). The stewardship of the samples refers to the preservation, hold times, and chain-of-custody of the samples. Appropriate preservation of samples (for example, placement of the samples on ice, or addition of an acid preservative) was maintained for all samples. Hold times refer to the maximum amount of time a sample can be preserved (mostly with ice) before it must be analyzed. All samples were analyzed within the appropriate hold times. The chain-of-custody ensures that the samples be accounted for from the time of sampling to the time the results are reported (U.S. Environmental Protection Agency, 2009). 
Table 2. Type of constituents sampled and method of analysis for stormwater samples at Fort Gordon, Georgia, 2011.

[USGS, U.S. Geological Survey; NWQL, USGS National Water Quality Laboratory; USEPA, U.S. Environmental Protection Agency; NPDES, National Pollutant Discharge Elimination System]

\begin{tabular}{|c|c|c|c|}
\hline Type & Laboratory schedule & NPDES method & Method description \\
\hline Volatile organic compounds & NWQL 1307 & $\begin{array}{l}\text { USGS O-4127-96 } \\
\text { (mod. USEPA 624) }\end{array}$ & $\begin{array}{l}\text { Purge-and-trap capillary-column } \\
\text { gas chromatography/mass } \\
\text { spectrometry }{ }^{1}\end{array}$ \\
\hline $\begin{array}{l}\text { Dissolved and whole water } \\
\text { nutrients }\end{array}$ & NWQL 2352 & USEPA 350.1 & $\begin{array}{l}\text { Phosphours and Kjeldahl digestion } \\
\text { method automated photometric } \\
\text { finish }^{2,3,4}\end{array}$ \\
\hline Trace metals in unfiltered water & NWQL 2351 & $\begin{array}{l}\text { USGS I-4471-97; } \\
\text { EPA } 200.8\end{array}$ & $\begin{array}{l}\text { Inductively coupled plasma-optical } \\
\text { emission spectrometry and } \\
\text { inductively coupled plasma-mass } \\
\text { spectrometry }^{4}\end{array}$ \\
\hline Chemical oxygen demand & & USGS I-3561-85 & $\begin{array}{l}\text { Colorimetric, dichromate } \\
\text { oxidation }^{3}\end{array}$ \\
\hline Hardness & & USEPA 200.7 & $\begin{array}{l}\text { Inductively coupled plasma- } \\
\text { optical emission spectrometry } \\
\text { and inductively coupled plasma- } \\
\text { mass spectrometry }{ }^{4}\end{array}$ \\
\hline Total suspended solids & & USGS I-3765 & $\begin{array}{l}\text { Residue at } 105 \text { degrees Celsius, } \\
\text { suspended, gravimetric }{ }^{2}\end{array}$ \\
\hline Oil and grease & $\begin{array}{l}\text { TestAmerica Contract } \\
\text { Item Number } 50136\end{array}$ & USEPA 1664 & $\begin{array}{l}\text { Hexane extractable material and } \\
\text { silica gel treated hexane extract- } \\
\text { able materiol (HEM \& SGT- } \\
\text { HEM) }\end{array}$ \\
\hline $\begin{array}{l}\text { Semi-volatile organic } \\
\text { compounds }\end{array}$ & NWQL 1383 & USGS O-3116-87 & $\begin{array}{l}\text { Continous liquid-liquid extraction } \\
\text { and capillary-column gas } \\
\text { chromatography and mass } \\
\text { spectrometry }^{2}\end{array}$ \\
\hline
\end{tabular}

${ }^{1}$ Connor, B.F., Rose, D.L., Noriega, M.C., Murtagh, L., Abney, S.R., 1997, Methods of analysis by the U.S. Geological Survey water quality laboratories-Determination of 86 volatile organic compounds in water by gas spectrometry, including detections less than reporting limits: U.S. Geological Survey Open File Report 97-829, 78 p.

${ }^{2}$ Fishman, M.J, ed., 1993, Methods of analysis by the U.S. Geological Survey National Water Quality Laboratory-Determination of inorganic constituents in water and fluvial sediments: U.S. Geological Survey Open-File Report 93-125, 217 p.

${ }^{3}$ Fishman, M.J, and Friedman, L.C., 1989, Methods for determination of inorganic substances in water and fluvial sediments: U.S. Geological Survey Techniques of Water-Resources Investigations, book 5, chapter A1, 545 p.

${ }^{4}$ Patton, C.J., and Kryskalla, J.R., 2003, Methods of analysis by the U.S. Geological Survey National Water Pollution LaboratoryEvaluation of alkaline persulfate digestion as an alternative to Kjeldhal digestion for determination of total and dissolved nitrogen and phosphorus in water: U.S. Geological Survey Open-File Report 03-4174, 33 p.

The chain-of-custody documents who is in possession of the samples at all times, from collection to the reporting of the results. The analytical service request form and lab login email served as the chain-of-custody documentation for the samples.

Water-quality data from each sampled event were reviewed for completeness, precision, bias, and transcription errors when received from the laboratory as part of the QA procedures. Collection and analysis of quality-control (QC) sample were part of this study. One field blank was collected during the sampling period. The field blank was used to evaluate if contamination from the sampling equipment and sample processing methods affected the environmental sample concentrations. Acceptable levels for field blank contamination are dependent on the data quality objectives of the investigation (U.S. Geological Survey, 2006). Because the data are for regulatory purposes, field blanks with detectable concentrations greater than 20 percent of (five times) the sample concentration were considered to require an action (U.S. Environmental Protection Agency, 1999b; 2004). Sample concentrations below the action level were rejected as unreliable due to potential contamination. Additional equipment and field blanks were collected to evaluate potential sources of the 
contamination. Water-quality and rainfall data are stored in the USGS National Water Information System (NWIS) database and quality-assured water-quality data are available for retrieval on the internet at http://waterdata.usgs.gov/sc/nwis/ sw. The USGS NWQL provides all QA/QC documentation for their analytical services on the internet at $h t t p: / / n w q l . u s g s . g o v /$ quality.shtml.

\section{Rainfall and Discharge}

The five outfall locations had an individual station name and number assigned by the USGS to allow data entry and archival into the NWIS database (fig. 2, table 1). Each outlet location was outfitted with an ISCO 6712 automatic sampler. This sampler includes tubing that is deployed at the sampling location, a pump to bring the sample up to the sampler, and pre-cleaned containers to collect the sample (Teledyne Isco, Inc., 2012). In addition, the automatic samplers have the capability of connecting precipitation gages to a data logger using a serial data interface at 12 Baud (SDI-12) (Teledyne Isco, Inc., 2012). The SDI-12 interface can be connected to a wide range of environmental sensors, and for this study, the data logger was connected to a continuous-recording tippingbucket precipitation gage, and to a 750 area velocity flow module (Teledyne Isco, Inc., 2007). The continuous-recording tipping-bucket precipitation gages were deployed at four of the five sites, because one of the industrial sites had two outfalls (H\&C plant \# 25910) and did not need to be equipped with a second precipitation gage (fig. 2, table 1). An equipment setup at a station (SWR11-5) with the precipitation gage and automatic sampler is shown in figure 4 .

Nonrecording precipitation gages also were deployed during storm events near the outfall site to collect precipitation data (U.S. Environmental Protection Agency, 1992; Church and others, 1999). Data from the nonrecording precipitation gages were used to confirm the results of the recording precipitation gages, and as a backup measurement of rainfall.

Discharge, or flow, was to be measured by the 750 area velocity module by determining the stage, or depth, of the stream in the culvert, the velocity of the stream in the culvert, and the culvert geometry. These parameters were recorded by the data logger in the sampler. In addition, discharge was computed by the indirect methods described by Bohdaine (1968) at sites SWR11-4 and SWR11-5. Indirect methods did not require the velocity to compute the discharge, because the control of the flow is located at the outlet of all the outlets that were sampled. The depth of flow at the outlet along with the slopes of the culvert which also were measured, provided sufficient data to compute the discharge.

To determine stage, the 750 area velocity module used an internal differential pressure transducer installed at the bottom of the culvert near the outlet. The transducer is a small piezoresistive disk that detects the pressures by a stainless-steel

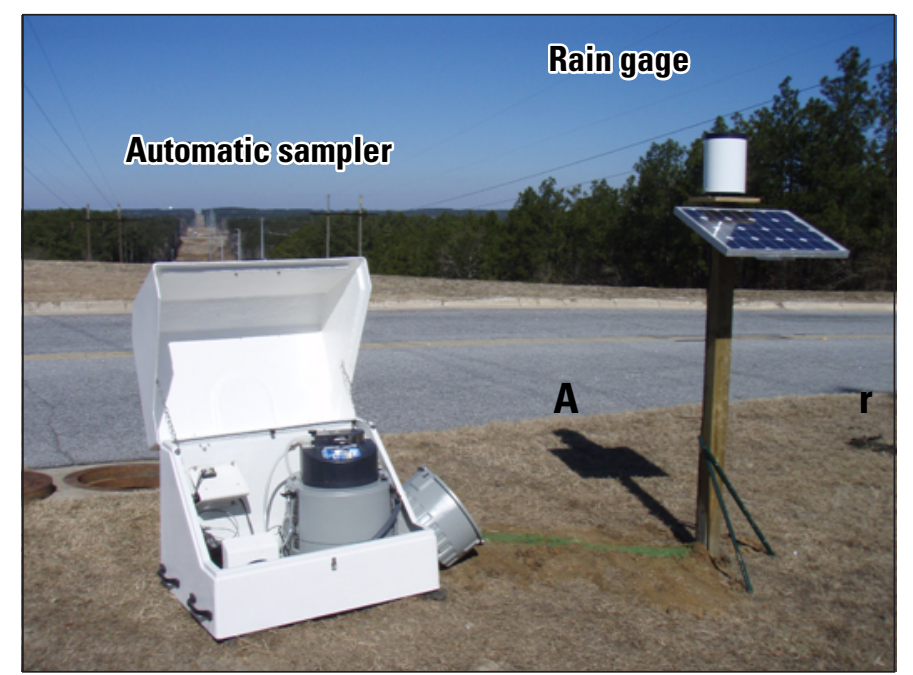

Figure 4. Automatic sampler and rain gage installed at selected industrial sites, Fort Gordon, Georgia.

diaphragm. The difference between the pressures exerted on the outer face on the diaphragm and the inner face of the diaphragm is called the hydrostatic pressure. Hydrostatic pressure is proportional to the level of the stream and converted to stage, therefore measuring the height above the transducer. Additionally, the stage was measured at the outlet of the culvert with a measuring tape throughout the sampling event. The 750 area velocity module also includes two transducers that measure velocity using ultrasonic sound waves and the Doppler effect. The first transducer emits an ultrasonic soundwave, and bubbles and suspended particles in the stream reflect the emitted soundwave back to a second transducer. The differences in the frequencies between the two soundwaves are proportional to the average velocity of the streamflow (Teledyne Isco, Inc., 2007). The culvert geometry was determined by measuring the diameter of the culvert through which the stormwater flows. The automatic sampler calculated the culvert cross section (or area) using the programmed culvert diameter and the stream level. This measurement was multiplied by the measured velocity to calculate the discharge (Teledyne Isco, Inc., 2006).

\section{Stormwater Sampling}

All samples collected were grab samples as described in the GaDNR general permit for discharges associated with industrial activities (Georgia Department of Natural Resources, 2006). The grab samples and discharge were collected at SWR11-3 by manually operating the automatic sampler, and at SWR11-4 and SWR11-5 by manually collecting the grab samples and indirectly computing the discharge. The grab samples were collected in pre-cleaned, acid-rinsed high density polypropylene (HDLP) containers after the criterion of $0.1 \mathrm{in}$. of rain was measured. The stormwater runoff samples were collected in the first 30 minutes of the runoff event (Georgia Department of Natural Resources, 2006). During 
the period of study at the two landfill sites, runoff in the first 30 minutes of the runoff event was not sufficient to produce adequate discharge from the stormwater outfalls. Stormwater sample collection during multiple storm events that exceeded the minimum 0.1 in. of rain criterion was attempted but aborted, because no runoff was produced (table 3 ).

\section{Results}

The results of the multiple stormwater sampling from three of the five different sampling stations that were scheduled to be sampled during the 2011 calendar year are presented in this section of the report. Sampling of the two landfill stations (SWR11-1 and SWR11-2) were not done from January to December 2011, because conditions did not permit a sample to be collected. Results of discharge, rainfall amounts, physical properties, suspended materials, nutrients and organic compounds, major and trace inorganic compounds, and volatile and semivolatile organic compounds from the $\mathrm{H} \& \mathrm{C}$ sites (SWR11-3, SWR11-4, and SWR11-5), are presented in subsequent sections.

\section{Quality Assurance and Quality Control}

Detections were identified in the field blank for some constituents. Generally, if the concentration in the blank(s) is less than 20 percent of the concentration in the environmental sample, the effect of contamination is likely to be within the precision of the method (U.S. Geological Survey 1997, 2006; U.S. Environmental Protection Agency, 1999b, 2004). Calcium, fluorene, and total nitrogen were all detected in the field blanks, but all at a level far below the levels of the results of the environmental samples, except for total nitrogen at station SWR11-5; therefore, the results of the environmental samples are considered reliable (table 4). The result for total nitrogen at station SWR11-5 was less than the order of magnitude of the concentration detected in the blank, but not enough to dismiss the result. The volatile organic compound diethyl phthalate was detected in the field blank at 0.32 microgram per liter $(\mu \mathrm{g} / \mathrm{L})$ and present in the environmental samples between less than 0.62 and $0.71 \mu \mathrm{g} / \mathrm{L}$; therefore, all results for diethyl phthalate are considered unreliable for all three stations (table 4). Di-n-butyl phthalate was detected in the field blank at $0.89 \mu \mathrm{g} / \mathrm{L}$, and two environmental samples had results of 5.06 (SWR11-4) and $6.18 \mu \mathrm{g} / \mathrm{L}$ (SWR11-5); therefore, those environmental samples were considered to be within acceptable accuracy (table 4). However, the di-n-butyl phthalate concentration at SWR11-3 was estimated at $0.78 \mu \mathrm{g} / \mathrm{L}$ and was considered unreliable (table 4). An estimated phenol concentration of $0.16 \mu \mathrm{g} / \mathrm{L}$ was detected in the field blank, and the results of the three samples show that one value (SWR11-4) was less than the censored value, but probably not enough to dismiss the result (table 4).

The greatest level of contamination in the field blank was with chemical oxygen demand and total organic carbon, and these levels suggested a systemic problem (table 4). Therefore, all chemical oxygen demand and total organic carbon concentrations in samples were considered unreliable. After investigation of sampling preparation and field procedures, the probable cause of the total organic carbon contamination was considered to be the methanol rinse step of the cleaning procedures. Methanol rinse of equipment used for organic sample collection is required to ensure removal of low-level organic contaminants; however, methanol residue can act as a contaminant for organic carbon analysis (Wilde, 2004). Additionally, methanol is readily biodegradable and methanol material safety data sheets indicate a relatively high chemical oxygen demand. Changes in cleaning procedures were implemented, and future follow-up equipment blanks will be conducted to verify the correction to the systemic problem.

Table 3. Streamflow and rainfall amounts, date that sample was collected, number of days from last measurable rain event, and duration of rain event, Fort Gordon, Georgia, 2011.

[USGS, U.S. Geological Survey; fts/s, cubic feet per second; NS, not sampled; EST, eastern standard time]

\begin{tabular}{|c|c|c|c|c|c|}
\hline $\begin{array}{l}\text { USGS station } \\
\text { name (figure 1) }\end{array}$ & Date of sample & $\begin{array}{c}\text { Number of days } \\
\text { from previously } \\
\text { measured storm } \\
\text { event }\end{array}$ & $\begin{array}{l}\text { Quantity of rain } \\
\text { (inches) }\end{array}$ & $\begin{array}{c}\text { Peak streamflow, } \\
\text { instantaneous } \\
\left(\mathrm{ft}^{3} / \mathrm{s}\right)\end{array}$ & $\begin{array}{c}\text { Duration of } \\
\text { hydrograph } \\
\text { (hours) }\end{array}$ \\
\hline${ }^{1}$ SWR11-1 & NS & NS & NS & NS & NS \\
\hline${ }^{1}$ SWR11-2 & NS & NS & NS & NS & NS \\
\hline SWR11-3 & $\begin{array}{l}\text { September 5, } 2011 \\
\text { Hour: 16:55 EST }\end{array}$ & 28 & 0.4 & 1.25 & 1 \\
\hline SWR11-4 & $\begin{array}{l}\text { October 18, } 2011 \\
\text { Hour: 20:30 EST }\end{array}$ & 7 & 0.6 & 1.92 & 6 \\
\hline SWR11-5 & $\begin{array}{l}\text { October 18, } 2011 \\
\text { Hour: 20:30 EST }\end{array}$ & 7 & 0.5 & 2.05 & 6 \\
\hline
\end{tabular}

${ }^{1}$ Station was scheduled to be sampled during the 2011 calendar year, but sampling was not done because criteria needed for sampling were not met. 
Table 4. Results of the field blank submited for the stormwater runoff sampling, Fort Gordon, Georgia, 2011.

[All units in micrograms per liter; <, less than; E, estimated]

\begin{tabular}{lcccc}
\hline \multirow{2}{*}{ Constituents } & $\begin{array}{c}\text { Field blank } \\
\text { concentration }\end{array}$ & \multicolumn{3}{c}{$\begin{array}{c}\text { Environmental sample } \\
\text { concentration }\end{array}$} \\
\cline { 3 - 5 } & & SWR11-3 & SWR11-4 & SWR11-5 \\
\hline Calcium & 0.024 & 1.552 & 0.915 & 1.13 \\
Fluorene & 0.003 & 0.065 & $<0.34$ & $<0.34$ \\
Total nitrogen & 0.057 & 1.723 & 0.786 & 0.356 \\
$\begin{array}{c}\text { Diethyl } \\
\text { phthalate }\end{array}$ & 0.32 & $<0.62$ & E 0.483 & E 0.709 \\
$\begin{array}{c}\text { Di-n-butyl } \\
\text { phthalate }\end{array}$ & 0.887 & E 0.778 & E 5.06 & E 6.18 \\
$\begin{array}{c}\text { Phenol } \\
\begin{array}{c}\text { Chemical } \\
\text { oxygen } \\
\text { demand }\end{array}\end{array}$ & E 0.164 & E 1.73 & E 0.96 & E 2.63 \\
$\begin{array}{c}\text { Organic } \\
\text { carbon }\end{array}$ & $2,542.5$ & 896 & 124.6 & 215 \\
\hline
\end{tabular}

\section{Rainfall and Discharge}

Samples were collected on September 5, 2011, at H\&C site SWR11-3, and on October 18, 2011, at H\&C sites SWR11-4 and SWR11-5 (table 3). Weather radars were observed to track incoming rain events, and USGS personnel were stationed at every station prior to the start of the rain event. No samples were collected at the two landfill stations in 2011, because sufficient rainfall needed to fill the detention or retention ponds did not occur. Rainfall amount for the September 5, 2011, storm event was 0.4 in. and lasted over a period of 1 hour with no prior rainfall for 28 days (table 3). Peak stormwater discharge at the time of sampling at site SWR11-3 was 1.25 cubic feet per second $\left(\mathrm{ft}^{3} / \mathrm{s}\right)$. On October 18, 2011, the storm event was 0.6 and 0.5 in. at sites SWR11-4 and SWR11-5, respectively, and lasted for a period of 6 hours with no prior rainfall for 7 days (table 3). Peak stormwater discharges at the time of sampling were 1.92 and $2.05 \mathrm{ft}^{3} / \mathrm{s}$ at SWR11-4 and SWR11-5, respectively.

At all three stations, the continuously recording precipitation gages did not function correctly; therefore, the precipitation results were obtained from the nonrecording precipitation gages. Although sites SWR11-4 and SWR11-5 were in close proximity, rainfall amounts differed by $0.1 \mathrm{in}$. for the two stations (table 3).

\section{Stormwater Sampling}

Field parameters (water temperature, specific conductance, dissolved oxygen, and $\mathrm{pH}$ ) were measured at all three stations before the samples were collected. Specific conductance values ranged from 12 to 46 microsiemens per centimeter at sites SWR11-5 and SWR11-3, respectively, during the study period. The $\mathrm{pH}$ values ranged from 4.3 to 6.9 standard units at sites SWR11-3 and SWR11-4, respectively. Dissolved oxygen concentrations ranged from 6.7 to 10.6 milligrams per liter (mg/L) at sites SWR11-3 and SWR11-5, respectively (table 5).

Suspended solid, nutrient, and major and trace inorganic compound concentrations were determined for the stormwater samples (tables 6-8). In general, constituent concentrations were relatively similar among sites. Total suspended solids, total fixed solids, and total volatile solids had concentrations below the LRL (less than 10 to less than $30 \mathrm{mg} / \mathrm{L}$ ) at all sites (tables 6-8). Total phosphorus concentrations ranged from 0.06 and $0.13 \mathrm{mg} / \mathrm{L}$ at sites SWR11-5 and SWR11-3, respectively (table 6-8). Site SWR11-3 had greater hardness, nitrogen (dissolved ammonia and total nitrogen), and zinc concentrations than sites SWR11-4 and SWR11-5 (tables 6-8).

Of the 87 volatile and semivolatile compounds that were analyzed in stormwater samples, 14 percent of the compounds were detected at site SWR11-3 (table 9), 24 percent were detected at site SWR11-4 (table 10), and 23 percent were detected at site SWR11-5 (table 11). At site SWR11-3, 7 of the 87 compounds were detected at concentrations above their LRLs and 5 were detected at estimated levels (table 9). Site SWR11-4 had 10 compounds detected at concentrations above their LRLs and 11 at estimated levels (table 10). Site SWR11-5 had 8 compounds detected at concentrations above their LRLs and 12 at estimated levels (table 11).

At site SWR11-3, 1, 2-dichloropropane, acenaphthylene, benzo [ghi] perylene, cis,1,2-dichloroethene, dimethyl phthalate, fluoranthene, and isophorone were all detected above their LRL (table 9). For station SWR11-4, the anthracene, benzo $[a]$ anthracene, benzo $[a]$ pyrene, benzo[ghi]pyrene, cis,1,2-dichloroethene, dimethyl phthalate, di-n-butyl phthalate, fluoranthene, naphthalene, and pyrene were all detected above their LRL (table 10). Finally, for station SWR11-5, anthracene, benzo[ $a]$ anthracene, benzo $[a]$ pyrene, benzo[ghi]perylene, dimethyl phthalate, fluoranthene, naphthalene, and pyrene were all detected above their LRL (table 11). 
Table 5. Field parameters detected in stormwater samples collected from selected stormwater industrial sites, Fort Gordon, Georgia, 2011.

\begin{tabular}{|c|c|c|}
\hline Parameter & Result & Concentration unit \\
\hline \multicolumn{3}{|c|}{ SW11-1 } \\
\hline Temperature & NS & degrees Celsius \\
\hline Specific conductance & NS & $\begin{array}{l}\text { microsiemens per centimeter } \\
\text { at } 25 \text { degrees Celsius }\end{array}$ \\
\hline Dissolved oxygen & NS & milligrams per liter \\
\hline Dissolved oxygen & NS & percent of saturation \\
\hline $\mathrm{pH}$ & NS & standard units \\
\hline \multicolumn{3}{|c|}{ SW11-2 } \\
\hline Temperature & NS & degrees Celsius \\
\hline Specific conductance & NS & $\begin{array}{l}\text { microsiemens per centimeter } \\
\text { at } 25 \text { degrees Celsius }\end{array}$ \\
\hline Dissolved oxygen & NS & milligrams per liter \\
\hline Dissolved oxygen & NS & percent of saturation \\
\hline $\mathrm{pH}$ & NS & standard units \\
\hline \multicolumn{3}{|c|}{ SW11-3 } \\
\hline Sample quantity & 1.06 & gallons \\
\hline Temperature & 29.4 & degrees Celsius \\
\hline Specific conductance & 46 & $\begin{array}{l}\text { microsiemens per centimeter } \\
\text { at } 25 \text { degrees Celsius }\end{array}$ \\
\hline Dissolved oxygen & 6.7 & milligrams per liter \\
\hline Dissolved oxygen & 89 & percent of saturation \\
\hline $\mathrm{pH}$ & 4.3 & standard units \\
\hline \multicolumn{3}{|c|}{ SW11-4 } \\
\hline Sample quantity & 1.06 & gallons \\
\hline Temperature & 22.9 & degrees Celsius \\
\hline Specific conductance & 31 & $\begin{array}{l}\text { microsiemens per centimeter } \\
\text { at } 25 \text { degrees Celsius }\end{array}$ \\
\hline Dissolved oxygen & 9.1 & milligrams per liter \\
\hline Dissolved oxygen & 112 & percent of saturation \\
\hline $\mathrm{pH}$ & 6.9 & standard units \\
\hline \multicolumn{3}{|c|}{ SW11-5 } \\
\hline Sample quantity & 1.06 & gallons \\
\hline Temperature & 22.3 & degrees Celsius \\
\hline Specific conductance & 12 & $\begin{array}{l}\text { microsiemens per centimeter } \\
\text { at } 25 \text { degrees Celsius }\end{array}$ \\
\hline Dissolved oxygen & 10.6 & milligrams per liter \\
\hline Dissolved oxygen & 130 & percent of saturation \\
\hline $\mathrm{pH}$ & 5.4 & standard units \\
\hline
\end{tabular}

Table 6. Suspended material, nutrients and organic compounds, and major and trace inorganic compounds detected in a single grab stormwater sample taken within the first 30 minutes of runoff from heating and cooling station SWR11-3, Fort Gordon, Georgia, September 5, 2011.

[All units in milligrams per liter; <, less than; NR, not reported; E, estimated]

\begin{tabular}{lc}
\hline Compound & Result \\
\hline \multicolumn{2}{c}{ Suspended material } \\
\hline Total suspended solids & $<15.0$ \\
Total fixed solids & $<15.0$ \\
Total volatile solids & $<10.0$ \\
\hline \multicolumn{2}{c}{ Nutrients and organic compounds }
\end{tabular}

Chemical oxygen demand

Organic Carbon, Total $\quad \mathrm{NR}^{1}$

Ammonia, as $\mathrm{NH}_{4} \quad 1.42$

Ammonia, as nitrogen $\quad 1.1$

$\begin{array}{ll}\text { Phosphorus } & 0.13\end{array}$

Total nitrogen $\quad 1.72$

\begin{tabular}{lc}
\hline \multicolumn{2}{c}{ Major and trace inorganic compounds } \\
\hline Hardness & 4.97 \\
Calcium, dissolved & 1.55 \\
Barium, dissolved & 0.010 \\
Magnesium, dissolved & 0.26 \\
Arsenic, total & 0.001 \\
Cadmium, total & 0.00087 \\
Chromium, total & 0.002 \\
Lead, total & 0.004 \\
Silver, total & $<0.002$ \\
Mercury, total & 0.000 \\
Selenium, total & 0.000 \\
Zinc, total & 0.218 \\
\hline
\end{tabular}

${ }^{1}$ Results of the analyses are not reported because the field blank results showed a problem with the cleaning procedure, and as a consequence, the environmental result was unreliable. 
Table 7. Suspended material, nutrients and organic compounds, and major and trace inorganic compounds detected in a single grab stormwater sample taken within the first 30 minutes of runoff from heating and cooling station SWR11-4, Fort Gordon, Georgia, October 18, 2011.

[All units in milligrams per liter; $<$, less than; NR, not reported; E, estimated]

\begin{tabular}{|c|c|}
\hline Compound & Result \\
\hline \multicolumn{2}{|c|}{ Suspended material } \\
\hline Total suspended solids & $<30.0$ \\
\hline Total fixed solids & $<30.0$ \\
\hline Total volatile solids & $<20.0$ \\
\hline
\end{tabular}

Chemical oxygen demand $\mathrm{NR}^{1}$

Organic Carbon, Total $\mathrm{NR}^{1}$

Oil and grease E 2.5

Ammonia, as $\mathrm{NH}_{4}$ 0.116

Ammonia, as nitrogen

0.09

Phosphorus

0.11

Total nitrogen

0.79

\section{Major and trace inorganic compounds}

Hardness

2.54

Calcium, dissolved

0.92

Barium, dissolved

0.009

Magnesium, dissolved

0.06

Arsenic, total

0.000

Cadmium, total

$<0.0004$

Chromium, total

0.002

Lead, total

0.009

Silver, total

Mercury, total

$<0.0006$

0.000

Selenium, total

0.000

0.083

Zinc, total

${ }^{1}$ Results of the analyses are not reported because the field blank results showed a problem with the cleaning procedure, and as a consequence, the environmental result was unreliable.
Table 8. Suspended material, nutrients and organic compounds, and major and trace inorganic compounds detected in a single grab stormwater sample taken within the first 30 minutes of runoff from heating and cooling station SWR11-5, Fort Gordon, Georgia, October 18, 2011.

[All units in milligrams per liter; $<$, less than; NR, not reported; E, estimated]

\begin{tabular}{lc}
\hline Compound & Result \\
\hline \multicolumn{2}{c}{ Suspended material } \\
\hline Total suspended solids & $<30.0$ \\
Total fixed solids & $<30.0$ \\
Total volatile solids & $<20.0$ \\
\hline \multicolumn{2}{c}{ Nutrients and organic compounds }
\end{tabular}

Chemical oxygen demand $\mathrm{NR}^{1}$

Organic Carbon, Total $\mathrm{NR}^{1}$

Oil and grease E 3.3

Ammonia, as $\mathrm{NH}_{4}$

Ammonia, as nitrogen

0.12

Phosphorus

0.06

Total nitrogen

0.36

Major and trace inorganic compounds

Hardness

3.13

Calcium, dissolved

Barium, dissolved

0.008

Magnesium, dissolved

0.075

Arsenic, total

0.001

Cadmium, total

$<0.0004$

Chromium, total

E 0.00073

Lead, total

0.002

Silver, total

$<0.0006$

Mercury, total

0.000

Selenium, total

0.000

Zinc, total

0.057

${ }^{1}$ Results of the analyses are not reported because the field blank results showed a problem with the cleaning procedure, and as a consequence, the environmental result was unreliable. 
Table 9. Volatile and semivolatile organic compounds detected in a single stormwater grab sample taken within the first 30 minutes of runoff from heating and cooling station SWR11-3, Fort Gordon, Georgia, September 5, 2011.

[All units in micrograms per liter; <, less than; E, estimated; NR, not reported]

\begin{tabular}{|c|c|}
\hline Compound & Result \\
\hline 1,2-Dichloroethane & $<0.2$ \\
\hline 1,2-Dichloropropane & 0.1 \\
\hline 1,4-Dichlorobenzene & $<0.1$ \\
\hline 2,4,6-Trichlorophenol & $<0.34$ \\
\hline 2,4-Dichlorophenol & Е 0.064 \\
\hline 2,4-Dimethylphenol & $<0.8$ \\
\hline 2-Methyl-4,6-dinitrophenol & $<2$ \\
\hline 4-Chloro-3-methylphenol & $<0.54$ \\
\hline 4-Nitrophenol & $<0.52$ \\
\hline Hexachlorobenzene & $<0.3$ \\
\hline Pentachlorophenol & $<0.6$ \\
\hline 1,1,1-Trichloroethane & $<0.1$ \\
\hline 1,1,2-Trichloro-1,2,2-trifluoroethane & $<0.1$ \\
\hline 1,1-Dichloroethane & $<0.1$ \\
\hline 1,1-Dichloroethene & $<0.1$ \\
\hline 1,2,4-Trichlorobenzene & $<0.26$ \\
\hline 1,2-Dichlorobenzene & $<0.1$ \\
\hline 1,2-Diphenylhydrazine & $<0.833$ \\
\hline 1,3-Dichlorobenzene & $<0.1$ \\
\hline 2,4-Dinitrophenol & $<2$ \\
\hline 2,4-Dinitrotoluene & $<0.56$ \\
\hline 2,6-Dinitrotoluene & $<0.4$ \\
\hline 2-Chloronaphthalene & $<0.16$ \\
\hline 2-Chlorophenol & $<0.26$ \\
\hline 2-Nitrphenol & $<0.4$ \\
\hline 3,3'-Dichlorobenzidine & $<0.42$ \\
\hline 4-Bromophenyl phenyl ether & $<0.24$ \\
\hline 4-Chlorophenyl phenyl ether & $<0.34$ \\
\hline 9H-Fluorene, water & $<0.34$ \\
\hline Acenaphthene & $<0.28$ \\
\hline Acenaphthylene & 0.3 \\
\hline Anthracene, water & $<0.38$ \\
\hline Benxene, water & $<0.1$ \\
\hline
\end{tabular}

Table 9. Volatile and semivolatile organic compounds detected in a single stormwater grab sample taken within the first 30 minutes of runoff from heating and cooling station SWR11-3, Fort Gordon, Georgia, September 5, 2011.-Continued

[All units in micrograms per liter; <, less than; E, estimated; NR, not reported]

\begin{tabular}{ll}
\hline Compound & Result
\end{tabular}

Benzo[a]anthracene

$<0.26$

Benzo $[a]$ pyrene

$<0.32$

Benzo $[b] \mathrm{b}$ fluoranthene

$<0.3$

Benzo[ghi]perylene

0.03

Benzo $[k]$ fluoranthene

$<0.3$

Benzyl n-butyl phthale

E 0.7

Bis(2-chloroethoxy) methane

$<0.24$

Bis (2-chloroethyl) ether

$<0.3$

Bis (2-chloroisopropyl) ether

$<0.14$

Bis (2-ethylhexyl phthalate

E 0.8

Bromodichloromethane

$<0.1$

Chlorobenzene

Chrysene, water

$<0.32$

cis, 1,2-Dichloroethene

Dibenzo $[a, h]$ anthracene

$<0.42$

Dibromochlormethane

$<0.2$

Dichlorodifluoromethane

$<0.2$

Dichloromethane

$<0.2$

Diethyl ether

$<0.2$

Diethyl phthalate

$\mathrm{NR}^{1}$

Diisopropyl ether

$<0.2$

Dimethyl phthalate

5.96

Di-n-butyl phthalate $\quad \mathrm{NR}^{1}$

Di-n-octyl phthalate

E 0.1

Ethylbenzene

$<0.1$

Fluoranthene

0.04

Hexachlorobutadiene

$<0.24$

Hexachlorocyclopentadieme

$<0.5$

Hexachloroethane

$<0.24$

Indeno [1,2,3-cd] pyrene

$<0.38$

Isophorone

Methyl-tert-butyl ether

$<0.2$

Methyl-tert-pentyl ether 
Table 9. Volatile and semivolatile organic compounds detected in a single stormwater grab sample taken within the first 30 minutes of runoff from heating and cooling station SWR11-3, Fort Gordon, Georgia, September 5, 2011.-Continued

[All units in micrograms per liter; <, less than; E, estimated; NR, not reported]

\begin{tabular}{|c|c|}
\hline Compound & Result \\
\hline $\mathrm{m}$-Xylene $+\mathrm{p}$-xylene & $<0.2$ \\
\hline Naphthalene & $<0.05$ \\
\hline Nitrobenzene & $<0.26$ \\
\hline n-Nitrosodimethylamine & $<0.24$ \\
\hline n-Nitrosodi-n-propylamine & $<0.4$ \\
\hline n-Nitrosodiphenylamine & $<0.28$ \\
\hline o-Xylene & $<0.1$ \\
\hline Phenanthrene & $<0.32$ \\
\hline Phenol & E 1.7 \\
\hline Pyrene & $<0.003$ \\
\hline Styrene & $<0.1$ \\
\hline tert-Butyl ethyl ether & $<0.1$ \\
\hline Tetrachloroethene & $<0.1$ \\
\hline Tetrachloromethane & $<0.2$ \\
\hline Toluene, water & $<0.1$ \\
\hline trans-1,2-Dichloroethene & $<0.1$ \\
\hline Tribromomethane & $<0.2$ \\
\hline Trichloroethene & $<0.1$ \\
\hline Trichlorofluoromethane & $<0.2$ \\
\hline Trichlormethane & $<0.1$ \\
\hline Trihalomethanes & $<0.6$ \\
\hline Vinyl chloride & $<0.2$ \\
\hline
\end{tabular}

${ }^{1}$ Results of the analyses are not reported because the field blank results showed a detected concentration of this constituent, and as a consequence, the environmental result was unreliable.
Table 10. Volatile and semivolatile organic compounds detected in a single stormwater grab sample taken within the first 30 minutes of runoff from heating and cooling station SWR11-4, Fort Gordon, Georgia, October 18, 2011.

[All units in micrograms per liter; $<$, less than; E, estimated; $\mathrm{NR}$, not reported]

$\begin{array}{ll}\text { Compound } & \text { Result }\end{array}$

1,2-Dichloroethane

$<0.2$

1,2-Dichloropropane

$<0.1$

1,4-Dichlorobenzene

$<0.1$

2,4,6-Trichlorophenol

$<0.34$

2,4-Dichlorophenol

$<0.36$

2,4-Dimethylphenol

$<0.8$

2-Methyl-4,6-dinitrophenol

$<2$

4-Chloro-3-nethylphenol

$<0.54$

4-Nitrophenol

E 0.19

Hexachlorobenzene

Pentachlorophenol

E 0.03

1,1,1-Trichloroethane

1,1,2-Trichloro-1,2,2-trifluoroethane

$<0.1$

1,1-Dichloroethane

1,1-Dichloroethene

1,2,4-Trichlorobenzene

$<0.26$

1,2-Dichlorobenzene

$<0.1$

1,2-Diphenylhydrazine

$<0.3$

1,3-Dichlorobenzene

2,4-Dinitrophenol

$<2$

2,4-Dinitrotoluene

$<0.56$

2,6-Dinitrotoluene

$<0.4$

2-Chloronaphthalene

$<0.24$

2-Chlorophenol

$<0.26$

2-Nitrophenol

E 0.14

3,3'-Dichlorobenzidine

$<0.42$

4-Bromophenyl phenyl ether $\quad<0.24$

4-Chlorophenyl phenyl ether $\quad<0.34$

9H-Fluorene, water

$<0.34$

Acenaphthene

$<0.28$

Acenaphthylene

E 0.02

Anthracene, water 
Table 10. Volatile and semivolatile organic compounds detected in a single stormwater grab sample taken within the first 30 minutes of runoff from heating and cooling station SWR11-4, Fort Gordon, Georgia, October 18, 2011.-Continued

[All units in micrograms per liter; <, less than; E, estimated; NR, not reported]

\begin{tabular}{|c|c|}
\hline Compound & Result \\
\hline Benxene, water & $<0.1$ \\
\hline Benzo $[a]$ anthracene & 0.16 \\
\hline Benzo[a]pyrene & 0.36 \\
\hline Benzo $[b] \mathrm{b}$ fluoranthene & E 0.67 \\
\hline Benzo $[g h i]$ perylene & 0.39 \\
\hline Benzo $[k]$ fluoranthene & E 0.28 \\
\hline Benzyl n-butyl phthale & $<1.8$ \\
\hline Bis(2-chloroethoxy) methane & $<0.24$ \\
\hline Bis (2-chloroethyl) ether & $<0.3$ \\
\hline Bis (2-chloroisopropyl) ether & $<0.14$ \\
\hline Bis (2-ethylhexyl phthalate & E 81 \\
\hline Bromodichloromethane & $<0.1$ \\
\hline Chlorobenzene & $<0.1$ \\
\hline Chrysene, water & E 0.36 \\
\hline$c i s, 1,2$ - Dichloroethene & 0.1 \\
\hline Dibenzo $[a, h]$ anthracene & $<0.42$ \\
\hline Dibromochlormethane & $<0.2$ \\
\hline Dichlorodifluoromethane & $<0.2$ \\
\hline Dichloromethane & $<0.2$ \\
\hline Diethyl ether & $<0.2$ \\
\hline Diethyl phthalate & $\mathrm{NR}^{1}$ \\
\hline Diisopropyl ether & $<0.2$ \\
\hline Dimethyl phthalate & 0.08 \\
\hline Di-n-butyl phthalate & 5.06 \\
\hline Di-n-octyl phthalate & $<0.6$ \\
\hline Ethylbenzene & $<0.1$ \\
\hline Fluoranthene & 0.63 \\
\hline Hexachlorobutadiene & $<0.24$ \\
\hline Hexachlorocyclopentadieme & $<0.5$ \\
\hline Hexachloroethane & $<0.24$ \\
\hline
\end{tabular}

Table 10. Volatile and semivolatile organic compounds detected in a single stormwater grab sample taken within the first 30 minutes of runoff from heating and cooling station SWR11-4, Fort Gordon, Georgia, October 18, 2011.-Continued

[All units in micrograms per liter; <, less than; E, estimated; NR, not reported]

\begin{tabular}{|c|c|}
\hline Compound & Result \\
\hline Indeno $[1,2,3$-cd] pyrene & Е 0.32 \\
\hline Isophorone & E 0.27 \\
\hline Methyl-tert-butyl ether & $<0.2$ \\
\hline Methyl-tert-pentyl ether & $<0.2$ \\
\hline $\mathrm{m}$-Xylene $+\mathrm{p}$-xylene & $<0.2$ \\
\hline Naphthalene & 0.03 \\
\hline Nitrobenzene & $<0.26$ \\
\hline n-Nitrosodimethylamine & $<0.32$ \\
\hline n-Nitrosodi-n-propylamine & $<0.442$ \\
\hline n-Nitrosodiphenylamine & $<0.48$ \\
\hline o-Xylene & $<0.1$ \\
\hline Phenanthrene & $<0.21$ \\
\hline Phenol & E 1 \\
\hline Pyrene & 0.5 \\
\hline Styrene & $<0.1$ \\
\hline tert-Butyl ethyl ether & $<0.1$ \\
\hline Tetrachloroethene & $<0.1$ \\
\hline Tetrachloromethane & $<0.2$ \\
\hline Toluene, water & $<0.1$ \\
\hline trans-1,2-Dichloroethene & $<0.1$ \\
\hline Tribromomethane & $<0.2$ \\
\hline Trichloroethene & $<0.1$ \\
\hline Trichlorofluoromethane & $<0.2$ \\
\hline Trichlormethane & $<0.1$ \\
\hline Trihalomethanes & $<0.6$ \\
\hline Vinyl chloride & $<0.2$ \\
\hline
\end{tabular}

${ }^{1}$ Results of the analyses are not reported because the field blank results showed a detected concentration of this constituent, and as a consequence, the environmental result was unreliable. 
Table 11. Volatile and semivolatile organic compounds detected in a single stormwater grab sample taken within the first 30 minutes of runoff from heating and cooling station SWR11-5, Fort Gordon, Georgia, October 18, 2011.

[All units in micrograms per liter; <, less than; E, estimated; NR, not reported]

\begin{tabular}{|c|c|}
\hline Compound & Result \\
\hline 1,2-Dichloroethane & $<0.2$ \\
\hline 1,2-Dichloropropane & $<0.1$ \\
\hline 1,4-Dichlorobenzene & $<0.1$ \\
\hline 2,4,6-Trichlorophenol & $<0.34$ \\
\hline 2,4-Dichlorophenol & $<0.36$ \\
\hline 2,4-Dimethylphenol & $<0.8$ \\
\hline 2-Methyl-4,6-dinitrophenol & $<2$ \\
\hline 4-Chloro-3-nethylphenol & $<0.81$ \\
\hline 4-Nitrophenol & E 0.41 \\
\hline Hexachlorobenzene & $<0.3$ \\
\hline Pentachlorophenol & E 0.1 \\
\hline 1,1,1-Trichloroethane & $<0.1$ \\
\hline 1,1,2-Trichloro-1,2,2-trifluoroethane & $<0.1$ \\
\hline 1,1-Dichloroethane & $<0.1$ \\
\hline 1,1-Dichloroethene & $<0.1$ \\
\hline 1,2,4-Trichlorobenzene & $<0.26$ \\
\hline 1,2-Dichlorobenzene & $<0.1$ \\
\hline 1,2-Diphenylhydrazine & $<0.3$ \\
\hline 1,3-Dichlorobenzene & $<0.1$ \\
\hline 2,4-Dinitrophenol & $<2$ \\
\hline 2,4-Dinitrotoluene & $<0.56$ \\
\hline 2,6-Dinitrotoluene & $<0.4$ \\
\hline 2-Chloronaphthalene & $<0.24$ \\
\hline 2-Chlorophenol & $<0.26$ \\
\hline 2-Nitrphenol & E 0.11 \\
\hline 3,3'-Dichlorobenzidine & $<0.42$ \\
\hline 4-Bromophenyl phenyl ether & $<0.24$ \\
\hline 4-Chlorophenyl phenyl ether & $<0.34$ \\
\hline 9H-Fluorene, water & $<0.06$ \\
\hline Acenaphthene & $<0.05$ \\
\hline
\end{tabular}

Table 11. Volatile and semivolatile organic compounds detected in a single stormwater grab sample taken within the first 30 minutes of runoff from heating and cooling station SWR11-5, Fort Gordon, Georgia, October 18, 2011.-Continued

[All units in micrograms per liter; <, less than; E, estimated; NR, not reported]

\begin{tabular}{lc} 
Compound & Result \\
\hline Acenaphthylene & E 0.05 \\
Anthracene, water & 0.14 \\
Benxene, water & $<0.1$ \\
Benzo[a]anthracene & 1.24 \\
Benzo[a]pyrene & 1.84
\end{tabular}

Benzo[b]b fluoranthene $\quad$ E 2.98

Benzo[ghi]perylene

Benzo $[k]$ fluoranthene

E 1.2

Benzyl n-butyl phthale

$<1.8$

Bis(2-chloroethoxy) methane $\quad<0.24$

Bis (2-chloroethyl) ether

$<0.34$

Bis (2-chloroisopropyl) ether

Bis (2-ethylhexyl phthalate

E 229

Bromodichloromethane

Chlorobenzene

Chrysene, water

E 2.16

cis,1,2- Dichloroethene

Dibenzo $[a, h]$ anthracene

Dibromochlormethane

$<0.2$

Dichlorodifluoromethane

$<0.2$

Dichloromethane

$<0.2$

Diethyl ether

$<0.2$

Diethyl phthalate

$\mathrm{NR}^{1}$

Diisopropyl ether

$<0.2$

Dimethyl phthalate

4.38

Di-n-butyl phthalate

E 6.18

Di-n-octyl phthalate

$<0.6$

Ethylbenzene

$<0.1$

Fluoranthene

4.56

Hexachlorobutadiene

$<0.24$

Hexachlorocyclopentadieme 
Table 11. Volatile and semivolatile organic compounds detected in a single stormwater grab sample taken within the first 30 minutes of runoff from heating and cooling station SWR11-5, Fort Gordon, Georgia, October 18, 2011.-Continued

[All units in micrograms per liter; <, less than; E, estimated; NR, not reported]

\begin{tabular}{|c|c|}
\hline Compound & Result \\
\hline Hexachloroethane & $<0.24$ \\
\hline Indeno $[1,2,3-\mathrm{cd}]$ pyrene & E 1.45 \\
\hline Isophorone & E 0.27 \\
\hline Methyl-tert-butyl ether & $<0.2$ \\
\hline Methyl-tert-pentyl ether & $<0.2$ \\
\hline m-Xylene + p-xylene & $<0.2$ \\
\hline Naphthalene & 0.04 \\
\hline Nitrobenzene & $<0.26$ \\
\hline n-Nitrosodimethylamine & $<0.32$ \\
\hline n-Nitrosodi-n-propylamine & $<0.4$ \\
\hline n-Nitrosodiphenylamine & $<0.48$ \\
\hline o-Xylene & $<0.1$ \\
\hline Phenanthrene & $<2.02$ \\
\hline Phenol & E 2.6 \\
\hline Pyrene & 3.47 \\
\hline Styrene & $<0.1$ \\
\hline tert-Butyl ethyl ether & $<0.1$ \\
\hline Tetrachloroethene & $<0.1$ \\
\hline Tetrachloromethane & $<0.2$ \\
\hline Toluene, water & $<0.1$ \\
\hline trans- 1,2-Dichloroethene & $<0.1$ \\
\hline Tribromomethane & $<0.2$ \\
\hline Trichloroethene & $<0.1$ \\
\hline Trichlorofluoromethane & $<0.2$ \\
\hline Trichlormethane & $<0.1$ \\
\hline Trihalomethanes & $<0.6$ \\
\hline Vinyl chloride & $<0.2$ \\
\hline
\end{tabular}




\section{Summary}

The U.S. Geological Survey, in cooperation with the U.S. Department of the Army Environmental and Natural Resources Management Office of the U.S. Army Signal Center and Fort Gordon, assessed the quantity and quality of stormwater runoff associated with industrial activities from January through December 2011. The assessment was conducted to satisfy the requirements from a general permit that authorizes the discharge of stormwater under the National Pollutant Discharge Elimination System from a site with industrial activities.

Stormwater runoff was scheduled to be sampled from five stations at four industrial sites (two landfills and two heating and cooling sites). The two landfill sites were not sampled, because no flow was observed at the outlets of the landfills during the 2011 calendar year. The assessment included the collection rainfall amounts, discharges, and physical properties (such as water temperature, specific conductance, dissolved oxygen, and $\mathrm{pH}$ ); the detection of suspended materials (total suspended solids, total fixed solids, total volatile solids), nutrients and organic compounds, and major and trace inorganic compounds; and the detection of volatile and semivolatile organic compounds. The largest rainfall amount was of 0.6 inch at station SWR11-4 and the greatest discharge was 2.05 cubic feet per second at station SWR11-5.

The stormwater samples also were analyzed for suspended materials (total suspended solids, total fixed solids, and total volatile solids), nutrients and organic compounds, major and trace inorganic (metals) compounds, and volatile and semivolatile organic compounds. The results for all three samples show that many of the constituents were detected above their laboratory reporting levels. In addition, the results for chemical oxygen demand and organic carbon were disregarded, because the results from the analyses of the field blanks indicated contamination related to cleaning of the sampling equipment with methanol.

Volatile and semivolatile compounds were detected at all three of the sampling stations above their laboratory reporting levels. Many volatile and semivolatile organic compounds were detected below their laboratory reporting levels but above their nondetection levels and, therefore, the levels were estimated. Various volatile and semivolatile organic compounds were detected above their laboratory reporting levels and included anthracene (SWR11-4 and SWR11-5), benzo[ $a$ ] anthracene (SWR11-4 and SWR11-5), benzo[a]pyrene (SWR11-4 and SWR11-5), benzo[ghi]perylene (SWR11-3, SWR11-4, and SWR11-5), cis,1,2-dichloroethene (SWR11-3, and SWR11-4), dimethyl phthalate (SWR11-3, SWR11-4, and SWR11-5), fluoranthene (SWR11-3, SWR11-4, and SWR11-5), naphthalene (SWR11-4, and SWR11-5), and pyrene (SWR11-4 and SWR11-5). In addition, acenaphthylene (SWR11-3), and di-n-butyl phthalate (SWR11-4) were detected above their laboratory reporting level at one sampling station each.

\section{Selected References}

Bohdaine, G.L., 1968, Measurement of peak discharge at culverts by indirect methods: U.S. Geological Survey Techniques of Water-Resources Investigations, book 3, chap. A3, $60 \mathrm{p}$.

Childress, C.J.O., Foreman, W.T., Connor, B.F., Maloney, T.J., 1999, New reporting procedures based on long-term method detection levels and some considerations for interpretations of water-quality data provided by the U. S. Geological Survey National Water Quality Laboratory: U.S. Geological Survey Open-File Report 99-193, 19 p.

Church, P.E., Granato, G.E., and Owens, D.W., 1999, Basic requirements for collecting, documenting, and reporting precipitation and storm-flow measurements: U.S. Geological Survey Open-File Report 99-255, 38 p.

Connor, B.F., Rose, D.L., Noriega, M.C., Murtagh, L., Abney, S.R., 1997, Methods of analysis by the U.S. Geological Survey water quality laboratories-Determination of 86 volatile organic compounds in water by gas spectrometry, including detections less than reporting limits: U.S. Geological Survey Open-File Report 97-829, 78 p.

Fishman, M.J, ed., 1993, Methods of analysis by the U.S. Geological Survey National Water Quality LaboratoryDetermination of inorganic constituents in water and fluvial sediments: U.S. Geological Survey Open-File Report 93-125, 217 p.

Fishman, M.J., and Friedman, L.C., 1989, Methods for determination of inorganic substances in water and fluvial sediments: U.S. Geological Survey Techniques of WaterResources Investigations, book 5, chapter A1, 545 p.

Garbarino, J.R., Kanagt, L.K., and Cree, M.E., 2006, Determination of elements in natural water, biota, sediment, and soil samples using collision/reaction cell inductively coupled plasma-mass spectrometry: U.S. Geological Survey Techniques and Methods, book 5, sec. B, chap. 1, 88 p.

Garbarino, J.R., and Damrau, D.L., 2001, Methods of analysis by the U.S. Geological Survey National Water Quality Laboratory-Determination of organic plus inorganic in filtered and unfiltered natural waters with cold vapor-atomic fluorescence spectrometry: U.S. Geological Survey WaterResources Investigations Report 01-4132, 16 p.

Garbarino, J.R., and Struzeski, T.M., 1998, Methods of analysis by the U.S. Geological Survey National Water Quality Laboratory-Determination of elements in wholewater digests using inductively coupled plasma-optical emissions spectrometry and inductively coupled plasmamass spectrometry: U.S. Geological Survey Open-File Report 98-165, $101 \mathrm{p}$. 
Georgia Department of Natural Resources, 2006, Authorization to discharge under the National Pollutant Discharge Elimination System — Storm water discharges associated with industrial activities, general NPDES stormwater permit No. GAR050000, effective date June 1, 2012, through May 31, 2017, accessed March 28, 2012, at http://www.gaepd. org/Documents /techguide_wpb.html.

Gregory, M.B., Stamey, T.C., and Wellborn, J.B., 2001, Ecological characterization of streams, and fish-tissue analysis for mercury and lead at selected locations, Fort Gordon, Georgia, June 1999 to May 2000: U.S. Geological Survey Open-File Report 01-203, 14 p.

Hoffman, G.L., Fishman, M.J., and Garbarino, J.R., 1996, Methods of analysis by the U.S. Geological Survey National Water Quality Laboratory-In bottle acid digestion of whole-water samples: U.S. Geological Survey Open-File Report 96-225, 28 p.

Patton, C.J., and Kryskalla, J.R., 2003, Methods of analysis by the U.S. Geological Survey National Water Pollution Laboratory-Evaluation of alkaline persulfate digestion as an alternative to Kjeldhal digestion for determination of total and dissolved nitrogen and phosphorus in water. U.S. Geological Survey Open-File Report 03-4174, 33 p.

Standard methods for the examination of water and wastewater, $21^{\text {st }}$ ed., 2005, method $5310 \mathrm{~B}$ high temperature combustion method, approved by the standard methods committee in 2000, accessed April 7, 2012, at http://www.standardmethods.org/store/ProductView.cfm? ProductID $=38$.

Teledyne Isco, Inc., 2012, 6712 Portable samplers installation and operation guide: Teledyne Isco, Inc., 246 p.

Teledyne Isco, Inc., 2007, 750 Area velocity module installation and operation guide: Teledyne Isco, Inc., 39 p.

Teledyne Isco, Inc., 2006, Flowlink 5 software instruction manual: Teledyne Isco, Inc., 147 p.

U.S. Environmental Protection Agency, 2004, USEPA Contract laboratory program national functional guidelines for inorganic data review: Washington, D.C., Office of Emergency and Remedial Response, EPA 540-R-04-004, 136 p.
U.S. Environmental Protection Agency, 1999a, Analytical methods-method 1664, revision A; n-hexane extractable material (HEM; oil and grease) and silica gel treated n-hexane extractable material (SGT-HEM; non-polar material) by extraction and gravimetry: Report EPA 821-R-98-002, 23 p.

U.S. Environmental Protection Agency, 1999b, USEPA contract laboratory program national functional guidelines for organic data review: Washington, D.C., Office of Emergency and Remedial Response, Report EPA 540-R-99-008, 118 p.

U.S. Environmental Protection Agency, 1992, National pollutant discharge elimination system storm water sampling guidance document: Washington, D.C., Office of Water, Report EPA 883-B-92-001, 177 p.

U.S Geological Survey, 2006, Collection of water samples (ver. 2.0): U.S. Geological Survey Techniques of Water-Resources Investigations, book 9, chap. A4, September 2006, accessed Arpil 10, 2012, at http://pubs.water.usgs.gov/twri9A4/

U.S Geological Survey, 1997, Office of Water-Quality technical memorandum 97.08, 2 p., Accessed April 10, 2012, at http://water.usgs.gov/admin/memo/QW/qw97.08.html.

U.S. Geological Survey, variously dated, National field manual for the collection of water-quality data: U.S. Geological Survey Techniques of Water-Resources Investigations, book 9, chaps. A1-A9, accessed March 26, 2012, at http:// pubs.water.usgs.gov/twri9A.

Wilde, F.D., ed., 2004, Cleaning of Equipment for water sampling (ver. 2.0): U.S. Geological Survey Techniques of Water-Resources Investigations, book 9, chap. A3, accessed May 31, 2011, at http://pubs.water.usgs.gov/twri9A3/.

Wilde, F.D., 2011, Water-quality sampling by the U.S. Geological Survey: Standard protocols and procedures: U.S. Geological Survey Fact Sheet, 2 p., accessed April 10, 2012, at http://pubs.usgs.gov/fS/2010/3121/.
Prepared by: USGS Science Publishing Network Raleigh Publishing Service Center 3916 Sunset Ridge Road

Raleigh, NC 27607
For additional information regarding this publication, contact: USGS South Carolina Water Science Center

Stephenson Center, Suite 129

720 Gracern Road

Columbia, SC 29210-7651

http://sc.water.usgs.gov 



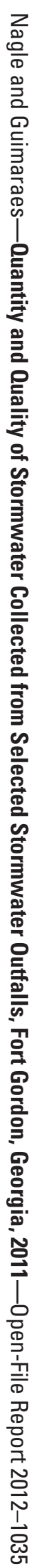

